\title{
Підвищення безпеки експлуатації будівель в умовах ущільнення забудови
}

\author{
О.С. Скрипник ${ }^{1}$, В.Є. Найдьонова ${ }^{2}$, М.Ю. Іващенко ${ }^{3}$, О.А. Шептур ${ }^{4}$ \\ 1, 3 Харківський національний університет міського господарства \\ ім. О.М. Бекетова, (м. Харків, Україна), етаil: elenases2015@gmail.com; \\ 3 marina.sh.225@gmail.com ORCID: 1 0000-0001-5926-755X; ${ }^{3}$ 0000-0002-9202-6448 \\ ${ }^{2}$ Харківський національний університет будівництва та архітектури, \\ (м. Харків, Україна), email: v.naidenova@ukr.net; ORCID: 0000-0002-9072-9561 \\ ${ }^{4}$ Харківський національний технічний університет сільського господарства імені \\ Петра Василенка (м. Харків, Україна), еmail: Sheptur1955@gmail.com; \\ ORCID: 0000-0002-9808-8041
}

\begin{abstract}
При зведенні будинків і підземних споруд в межах сучасного міста в умовах ущільнення забудови найчастіше не вдається проводити роботи таким чином, щоб зовсім не впливати на будинки, що знаходяться в безпосередній близькості від нового будівництва. В результаті робіт по екскавації котлованів і подальшого влаштування несучих конструкцій підземних споруд існуючі будинки можуть зазнавати нерівномірні осідання. У їх стінах з'являються тріщини або відбуваються порушення експлуатаційної придатності окремих конструктивних елементів тим самим являючись чинником техногенної небезпеки для людей. В статті подано розгляд та аналіз способів посилення основ і фундаментів експлуатованих будівель що піддаються впливу навантажень від будівельних робіт під час екскавації.

Виявлено, що вирішення проблеми виникнення аварійних ситуацій та безпеки експлуатації існуючих будівель в умовах ущільнення у багатьох випадках можна запобігти, якщо професійно і В повному обсязі проводити моніторинг майданчика будівництва заглиблених споруд. Виникнення додаткових просідань існуючих будівель і споруд в умовах ведення поруч з ними нового будівництва може бути пов'язано з великою кількістю причин. У статті виділено типи додаткових просідань існуючих будівель.

Для забезпечення безпечної експлуатації будівель запропоновано аналіз способів закріплення ґрунтів. Враховуючи інженерно-геологічні умови майданчика будівництва, що завжди першими визначають можливий спосіб закріплення ґрунтів за різними технологіями, проаналізовано способи укріплення ґрунтів, виявлено їх переваги і недоліки. Застосування буроін'єкційних паль є універсальним способом виробництва робіт
\end{abstract}

Ключові слова: безпека, аварія, основа, фундаменти, просідання, посилення основ і фундаментів

Постановка проблеми. Не дивлячись на всі зусилля проектувальників, науковців в умовах ущільнення існуючої забудови при будівництві заглиблених будівель та споруд можуть виникати аварійні ситуації. В основному вони бувають пов'язані з помилками в проектуванні. Наприклад, в результаті допущення помилок проектування захисна конструкція котловану може виявитися недостатньо міцною або стійкою. При будівництві це призводить до значних переміщень самої захисної конструкції котловану, а в деяких випадках і до ії обвалення.

До помилок проектування також може бути віднесена недостатню вивченість інженерно-геологічних умов майданчика будівництва, що не дає можливості врахувати в проекті всі можливі ризики геотехнічного будівництва.

Інша можлива причина аварійних ситуацій незадовільна якість виконання робіт. Слід мати на увазі, що роботи по влаштуванню глибоких котлованів (понад 5 м) можна віднести до складних видів геотехнічних робіт, які повинні виконуватися в суворій відповідності з розробленою технологією під контролем проектної організації і представників Замовника.

Окрім того можливо також поєднання декількох несприятливих факторів, які призводять до аварійних ситуацій.

Аналіз останніх досліджень і публікацій. При зведенні будинків і підземних споруд в межах сучасного міста в умовах ущільнення забудови найчастіше не вдається проводити роботи таким чином, щоб зовсім не впливати на будинки, що знаходяться в безпосередній близькості від нового будівництва. В результаті робіт по екскавації котлованів і подальшого влаштування несучих конструкцій підземних споруд існуючі будинки можуть зазнавати нерівномірні осідання. У їх стінах з'являються тріщини або відбуваються порушення експлуатаційної придатності окремих 
конструктивних елементів тим самим являючись чинником техногенної небезпеки для людей.

Актуальність дослідження обумовлюється тим що для забезпечення безпеки існуючих будівель і споруд завжди виникає необхідність достовірного прогнозу додаткових деформацій існуючих будівель і споруд. Якщо ці прогнозовані додаткові деформації становлять загрозу для нормальної експлуатації будівель, проектувальнику необхідно розробити комплекс спеціальних заходів, які дозволяють захистити фундаменти і основні несучі конструкції існуючих будинків, а якщо уникнути негативного впливу не вдається, поставити питання про перегляд концепції нового будівництва. Завжди стоїть завдання визначення габаритів так званої «зони впливу будівництва» - такої ділянки, на якому можуть відбуватися будь-які негативні процеси, викликані будівельними роботами.

Метою дослідження є розгляд та аналіз способів посилення основ і фундаментів експлуатованих будівель що піддаються впливу навантажень від будівельних робіт під час екскавації.

Виклад основного матеріалу. Виникнення додаткових просідань існуючих будівель і споруд в умовах ведення поруч з ними нового будівництва може бути пов'язано з великою кількістю причин [1]. Можна виділити кілька типів додаткових просідань існуючих будівель:

Просідання, пов'язані зі зміною напружено-деформованого стану ґрунтового масиву, викликаного новим будівництвом. Просідання зазначеного типу в більшості випадків можуть бути достовірно визначені на підставі чисельного моделювання по спеціалізованим геотехнічних програмами.

Просідання, пов'язані 3 температурними впливами в процесі влаштування нових підземних споруд. Вони зазвичай проявляються в температурних деформаціях розпірок і огороджувальних конструкцій котловану, що викликає додаткові переміщення прилеглого ґрунтового масиву. При проведенні розрахунків зазвичай враховуються сили морозного здимання від промерзання грунту, що взаємодіє з підземною спорудою. Просідання зазначеного типу можуть визначатися на підставі чисельного моделювання при проведенні спеціальних теплотехнічних і деформаційних розрахунків.

Просідання, пов'язані з пристроєм огороджувальних конструкцій котлованів або ґрунтових анкерів, посиленням існуючих будівель в потенційній зоні впливу будівництва. Просідання зазначеного типу не можуть бути в більшості випадків визначені чисельними методами. Прогноз можливий на підставі узагальнення даних моніторингу з використанням будь-якої технології на об'єктах-аналогах, що знаходяться в схожих інженерно-геологічних умовах.

Просідання, пов'язані з частковим розбиранням будівлі або сусідніх будівель і споруд. За- значений тип просадок багато в чому залежить від випадкових фракторів, наприклад, наявності загальних стін і перекриттів, що зноситься і залишені будівлі. Дані моніторингу для прогнозу просадок зазначеного типу мало інформативні.

Просідання, пов'язані зі зміною гідрогеологічної ситуації в процесі будівництва. У більшості випадків їх виникнення пов'язане з будівельним водозниженням або з проявом баражного ефекту в період після закінчення будівництва. Прогноз зазначених просідань здійснюється на підставі прогнозу зміни гідрогеологічної ситуації в ході будівництва, а також на підставі розрахунків по спеціалізованим геотехнічних програмами. Просідання зазначеного типу можуть прогнозуватися 3 достатньою часткою вірогідності.

Просідання, пов'язані 3 порушеннями в послідовності виробництва або в технології виконуваних робіт. Помилки зазначеного типу не можуть бути спрогнозовані, але можуть бути передбачені. У більшості випадків запобігання просаджень зазначеного типу покладається на авторський нагляд, технічний нагляд замовника, а також на форми, які здійснюють моніторинг і науковотехнічний супровід будівництва.

Просідання, пов'язані з ударними або динамічними впливами. Можуть прогнозуватися на підставі даних чисельного моделювання та дослідних робіт, які виконуються безпосередньо на будівельному майданчику.

Просідання, пов'язані з тривалими процесами в прилеглому ґрунтовому масиві, природа яких часто не може бути достовірно визначена. До просідань даної категорії можна віднести просадочні процеси, пов'язані з витоками води з підземних комунікацій, суфозійними і карстові процеси, "вікові" просідання і т.д. Просідання зазначеного типу можуть прогнозуватися на підставі тривалих спостережень за станом ґрунтового масиву, зміною рівня ґрунтових вод і геодезичними спостереженнями за існуючими будівлями.

Таким чином, існує значна кількість можливих причин появи додаткових деформацій існуючих будівель при веденні в безпосередній близькості від них нового будівництва. Знаючи причини негативного впливу нового будівництва на існуючі будівлі, можна спробувати мінімізувати їх можливі деформації.

Рішення зазначеної задачі здійснюється шляхом чисельного моделювання впливу нового будівництва на навколишню забудову, узагальнення досвіду будівництва об'єктів-аналогів [2]. Інженерний досвід, велика і кропітка робота i трохи везіння - ось запорука успіху при веденні будівництва підземних споруд в умовах тісної міської забудови. Запобігання додаткових деформацій не може бути досягнуто без ретельного контролю над усіма процесами на будівельному 
майданчику, веденням технічного і наукового супроводу будівництва. Мінімізація впливу нового будівництва також може бути здійснена шляхом виконання підсилення фундаментів будівель навколишньої забудови або їх несучих конструкцій.

Достовірне прогнозування впливу нового будівництва на навколишню забудову є запорукою подальшого безпечного будівництва [3, 4]. На даний момент ствердилася світова практика, коли новому будівництву передує чисельне моделювання впливу нового будівництва на навколишню забудову, яке виконує спеціалізованими геотехнічними фрірмами.

Для виконання достовірного прогнозу впливу зведення підземної споруди на навколишню забудову в першу чергу виникає питання вибору програмного забезпечення.

Чисельне моделювання є досить тонким процесом, та повною мірою залежить від досвіду. Необхідно побудувати чітку розрахункову схему, здатну описати найбільш важливі особливості механічної роботи конструкцій, на які оцінюється вплив. Важливо правильно описати роботу огороджувальних конструкцій котловану, основні особливості їх взаємодії з навколишнім ґрунтом. У розрахунковій моделі має бути Відображено порядок зведення всіх конструкцій, з достатньою часткою точності задані величини навантажень, що передаються на основу. Для правильного опису роботи по контакту «огорожа - котлован ґрунт» в розрахункову модель зазвичай вводяться спеціальні інтерфейсні елементи.

Після проведення чисельного моделювання може бути вирішене питання про необхідність посилення фундаментів або несучих конструкцій існуючої будівлі. На підставі чисельного моделювання можуть бути визначені габарити «зони впливу будівництва», а також розміри ділянки, на якому необхідно проведення робіт з підсилення основ і фундаментів.

В даний час $є$ значна кількість способів посилення основ і фундаментів будівель, наведемо деякі з них:

1. Різні способи хімічного закріплення ґрунтів основи: силікатизація (однорозчинна і дворозчинна), смолізація і цементація ґрунтів, закріплення матеріалами типу "Мікродур".

2. Підсилення фундаментів шляхом влаштування бурових паль (мікропаль).

3. Підсилення фундаментів методом задавливання паль.

4. Підсилення фундаментів і основ з використанням струменевої технології за класичною технологією і технології типу Mini-jet або Mono-jet.

5. Способи улаштування відсічних екранів або ґеобарьерів.

6. Армування основ.

7. Різні способи компенсаційного нагнітання.
8. Збільшення опорної площі фундаментів, підведення залізобетонних плит.

9. Зміна конструктивної схеми будівлі, влаштування металевих поясів і тяжів.

Очевидно, що всі зазначені вище способи мають свої переваги і недоліки. Перше, що завжди визначає можливий спосіб закріплення ґрунтів за різними технологіями, $є$ інженерно-геологічні умови майданчика будівництва. На схемі, представленої на рис. 1, показано в яких ґрунтах можуть застосовуватися різні способи закріплення ґрунтів.

\begin{tabular}{|c|c|c|c|}
\hline $\begin{array}{l}\text { Гравелисті } \\
\text { Грунти }\end{array}$ & Піски & $\begin{array}{l}\text { Супіски і } \\
\text { суглинки }\end{array}$ & Глини \\
\hline \multicolumn{4}{|l|}{\begin{tabular}{|c|} 
Цементація \\
ґрунтів
\end{tabular}} \\
\hline & \multicolumn{2}{|c|}{$\begin{array}{c}\text { Закріплення } \\
\text { матеріалами типу } \\
\text { "Мікродур". }\end{array}$} & \\
\hline \multicolumn{4}{|c|}{ Хімічне закріплення ґрунтів } \\
\hline & \multicolumn{3}{|c|}{ Влаштування задавлених паль } \\
\hline \multicolumn{4}{|c|}{ Влаштування буроін'єкційних паль } \\
\hline \multicolumn{4}{|c|}{$\begin{array}{c}\text { Зкріпленння по струменевій технології } \\
\text { (jet-grouting) }\end{array}$} \\
\hline \multicolumn{4}{|c|}{$\begin{array}{c}\text { Влаштування відсічних екранів і ґеотехнічних } \\
\text { бар'єрів }\end{array}$} \\
\hline & & \multicolumn{2}{|c|}{$\begin{array}{c}\text { Електро-хімічне } \\
\text { закріплення } \\
\text { Електроосмос }\end{array}$} \\
\hline
\end{tabular}

Рис. 1 Можливість застосування різних способів посилення основ і фундаментів в залежності від ґрунтових умов

3 наведеної вище схеми видно, що застосування буроін'єкційних паль є універсальним способом виробництва робіт. $Є$ величезна кількість варіацій у використанні зазначеного способу. Палі РІТ (виконувані по раз рядно - імпульсної технології), палі «ГЕО», палі, влаштовуються за технологією CFA, і інші способи влаштування буроін'єкційних паль давно відомві. До недоліків зазначеного способу варто віднести, що палі зазначеного типу мають відносно невелику жорсткість, а при їх виготовленні часто виникають значні за величиною технологічні просідання. Для зменшення величини технологічних осад паль починають використовуватися нові будівельні технології, коли палі влаштовуються втрачає буровими штангами (палі Titan i Gevi [8]). Бурові штанги спочатку використовуються для буріння, а потім слугують армуючим елементом влаштованих паль. У якості бурового розчину застосовують цементний розчин, який після затвердіння формує тіло палі. До недоліків способу слід віднести високу вартість бурових штанг імпортного виробництва. Освоєння вітчизняними заводами зазначеної технології дає змогу істотно знизити вартість виготовлення паль, зробивши спосіб конкурентоспроможним. 
На наведеної вище схемою видно, що більшість способів хімічного закріплення ґрунтів може бути застосовано тільки в піщаних ґрунтах. При цьому при виборі раціональної схеми і форми закріпленої основи повинні враховуватися гідрогеологічні умови ділянки, недооцінка яких може привести до серйозних наслідків $[7,8]$. Нераціональне хімічне закріплення ґрунтів може призвести до зниження несучої здатності основи і до значних просідань.

Зміна конструктивної схеми будівлі взагалі $€$ вкрай проблематичним технічним рішенням, оскільки може бути змінено архітектурний вигляд будинку, а влаштування тяжів в квартирах, в яких знаходяться люди, майже завжди проблематично.

Самі способи посилення основ продовжують удосконалюватися. Виникають нові різні способи, які не використовувалися до теперішнього часу.

Висновки. У багатьох випадках аварійні ситуації можна запобігти, якщо професійно і в повному обсязі проводити моніторинг майданчика будівництва заглиблених споруд. Він має істотне значення, оскільки дає можливість отримувати оперативну інформацію про можливі зміни в стані огороджувальної конструкції, ґрунтовому масиві, конструкціях існуючих будівель і споруд, в тому числі підземних водоносних комунікацій.

\section{Література}

1. Кураш С.Ю. Застосування теорії збалансованого ризику для визначення вірогідності характеристик слабких ґрунтів в умовах щільної міської забудови. / Кураш С.Ю., Калюх Ю.І., Хавкін О.К., Калюх Т.Ю. // Науково- технічний збірник «Сучасні технології, матеріали і конструкції в будівництві». 2011. № 1. - С. 71-75.

2. Калюх Ю.І. Теоретична концепція та практична реалізація нової інтегрованої методології систем раннього попередження про зсувну небезпеку / Калюх Ю.І., Іщенко Ю.І. // Наука та будівництво, 2020. № 1.- С. 3-17.

3. Основи та фундаменти будівель і споруд: Основні положення. ДБН В.2.1-10:2018. - [Чинні від 2019-01-01]. К.: Мінрегіон України, 2018. (Будівельні норми України).

4. Система надійності та безпеки в будівництві. Будівництво в умовах ущільненої забудови. Вимоги безпеки. ДБН В. 1.21-12-2008. -
[Чинні від 2019-01-01].. К. : Мінрегіонбуд, 2008. 34 с. - (Будівельні норми України).

5. Будівництво в умовах ущільненої забудови. Вимоги безпеки. ДБН В.1.2-12-2008. - [Чинні від 2009-01-01]. К.: Укрбудархінформ. 2007. 34 с. - (Будівельні норми України).

6. Загальні принципи забезпечення надійності та конструктивної безпеки будівель і споруд ДБН В.1.2-14:2018. - [Чинні від 2019-01-01].. К.: Укрбудархінформ. 2018. 30 с. - (Будівельні норми України).

7. Соколович В.Е. Химическое закрепление грунтов / Соколович В.Е.. Москва. - Стройиздат. 1980

8. Новые пути в анкерной технике. Проектирование и расчет. Анкерные сваи ISCHEBECK. «TITAN». Рекламные материалы фрирмы ISCHEBECK (Германия). 2006 г.

\section{References}

1. Kurash, S.Yu., Kaliukh, Yu.I., Khavkin, O.K. and Kaliukh, T.Yu. (2011) "Zastosuvannia teorii zbalansovanoho ryzyku dlia vyznachennia virohidnosti kharakterystyk slabkykh gruntiv $v$ umovakh shchilnoi miskoi zabudovy", Naukovo - tekhnichnyi zbirnyk «Suchasni tekhnolohii, materialy i konstruktsii v budivnytstvi, (1), pp. 71-75.

2. Kaliukh, Yu.I. and Ishchenko, Yu.I. (2020) "Teoretychna kontseptsiia ta praktychna realizatsiia novoi intehrovanoi metodolohii system rannoho poperedzhennia pro zsuvnu nebezpeku“, Nauka ta budivnytstvo,(1). pp. 3-17.

3. (2019). Osnovy ta fundamenty budivel i sporud: Osnovni polozhennia. DBN V.2.1-10:2018.

4. (2019). Systema nadiinosti ta bezpeky $v$ budivnytstvi. Budivnytstvo $v$ umovakh ushchilnenoi zabudovy. Vymohy bezpeky. DBN V. 1.21-12-2008.

5. (2009) Budivnytstvo v umovakh ushchilnenoi zabudovy. Vymohy bezpeky. DBN V.1.2-12-2008.

6. (2019) Zahalni pryntsypy zabezpechennia nadiinosti ta konstruktyvnoi bezpeky budivel i sporud DBN V.1.2-14:2018.

7. Sokolovich, V.E. (1980) Khimicheskoye zakrepleniye grunto. Moscow:. - Stroyizdat. 1980, 119 p.

8. Ischebeck Titan. (n.d.). Ischebeck Titan | Formwork \& Falsework | Ground Engineering. [online] Available at: https://www.ischebeck-titan.co.uk/ [Accessed 25 Dec. 2020].

\section{Аннотация}

\section{Повышение безопасности эксплуатации зданий в условиях уплотнения застройки}

\section{Е.С. Скрипник, В.Е. Найдьонова, М.Ю. Иващенко, А.А. Шептур}

При возведении зданий и подземных сооружений в пределах современного города в условиях уплотнения застройки зачастую не удается проводить работы таким образом, чтобы совсем не влиять на дома, находящиеся в непосредственной близости от нового строительства. В результате работ по экскавации котлованов и дальнейшего устройства несущих конструкций подземных сооружений существующие дома могут испытывать неравномерные осадки. В их стенах появляются трещины или 
происходят нарушения эксплуатационной пригодности отдельных конструктивных элементов тем самым являясь фактором техногенной опасности для людей.В статье представлено обзор и анализ способов усиления оснований и фундаментов эксплуатируемых зданий подвергающихся воздействию нагрузок от строительных работ при экскавации.

Выявлено, что решение проблемы возникновения аварийных ситуаций и безопасности эксплуатации существующих зданий в условиях уплотнения во многих случаях можно предотвратить, если профессионально и в полном объеме проводить мониторинг площадки строительства заглубленных сооружений. Возникновение дополнительных просадок существующих зданий и сооружений в условиях ведения рядом с ними нового строительства может быть связано с большим количеством причин. В статье выделены типы дополнительных просадок существующих зданий.

Для обеспечения безопасной эксплуатации зданий предложено анализ способов закрепления грунтов. Учитывая инженерно-геологические условия площадки строительства, всегда первыми определяют возможный способ закрепления грунтов по различным технологиям, проанализированы способы укрепления грунтов, выявлены их преимущества и недостатки. Применение буроинъекционных свай является универсальным способом производства работ.

Ключевые слова: безпека, аварія, основа, фундаменти, просідання, посилення основ і фундаментів

\section{Abstract \\ Improving the safety of buildings operation in terms of building density}

\section{O.S. Skrypnyk, V.E. Naidonova, M.Yu. Ivashchenko, O.A. Sheptur}

When erecting buildings and underground structures in cities, it is often not possible to carry out work safely in the conditions of building compaction. It is impossible not to affect the houses in the immediate vicinity of the new construction. As a result of excavation work on the ditches of the load-bearing structures of underground structures, existing houses may experience uneven rainfall. Cracks appear in the walls or there are violations of the serviceability of individual structural elements. This is a factor of man-made danger to humans. The article presents an overview and analysis of ways to strengthen the foundations and foundations of existing buildings exposed to loads from construction work during excavation.

It was revealed that the solution of the problem of emergencies and safety of operation of existing buildings in the conditions of compaction of construction in many cases can be prevented if professionally and in full to monitor the construction site of sunken structures. The occurrence of additional subsidence of existing buildings and structures in the conditions of conducting new construction next to them can be due to a large number of reasons. The article highlights the types of additional drawdowns of existing buildings.

To ensure the safe operation of buildings, an analysis of soil consolidation methods is proposed. Taking into account the engineering and geological conditions of the construction site, possible ways of fixing the soil by various technologies have been identified. Methods of soil strengthening are analyzed, their advantages and disadvantages are revealed. Application of borehole injection piles is a universal way of production of works

Keywords: безпека, аварія, основа, фундаменти, просідання, посилення основ і фундаментів

Бібліографічне посилання/ Bibliography citation: Harvard

Skrypnyk, O. S. et al. (2020) 'Improving the safety of buildings operation in terms of building density', Engineering of nature management, (4(18), pp. 95 - 99.

Подано до редакції / Received: 02.10.2020

ISSN 2311-1828

http://enm.khntusg.com.ua
Інженерія природокористування, 2020, №4(18), с. 95 - 99

Engineering of nature management, 2020, \#4(18), p. 95 - 99 